\title{
Unscarred uterine rupture: a retrospective analysis in tertiary center
}

\section{Madhureema Verma, Radheshyam Bairwa*}

Department of Obstetrics and Gynecology, Jhalawar Medical College, Jhalawar, Rajasthan, India

Received: 01 February 2018

Accepted: 26 February 2018

\section{*Correspondence:}

Dr. Radheshyam Bairwa,

E-mail: apurvagarg89@gmail.com

Copyright: (c) the author(s), publisher and licensee Medip Academy. This is an open-access article distributed under the terms of the Creative Commons Attribution Non-Commercial License, which permits unrestricted non-commercial use, distribution, and reproduction in any medium, provided the original work is properly cited.

\section{ABSTRACT}

Background: Uterine rupture is a catastrophic obstetrical emergency associated with a significant fetomaternal morbidity and mortality. Many risk factors for uterine rupture, as well as a wide range of clinical presentations have been identified. The objectives of the present study were to analyze the frequency, predisposing factors, maternal and fetal outcomes of unscarred uterine rupture.

Methods: A retrospective analysis of cases of unscarred uterine rupture was conducted at the Department of Obstetrics and Gynaecology Jhalawar medical college Jhalawar Rajasthan from January 2009 to December 2016.

Results: Our analysis comprised of 11 cases with unscarred uterine rupture. Incidence of unscarred uterine rupture is $0.01 \%$ or $1 / 10,000$ deliveries.

Conclusions: In our study there was no history of uterine scarring so the main predisposing factor are maltiparity and obstructed labour. The grand multiparas women and obstructed labour must be managed by proper trained personnel and in tertiary care center in order to avoid the morbidity and mortality.

Keywords: Obstructed labour, Uterine rupture, Unscarred uterus

\section{INTRODUCTION}

The high parity is recognized as major risk factor of spontaneous uterine rupture in unscarred uterus. ${ }^{1}$

In developing countries, the incidence is high due to a greater number of unbooked obstetric emergencies, after originating from rural areas with poor antenatal care. The most common cause of rupture uterus in teaching and referral hospital are previous cesarean section deliveries. ${ }^{2}$

Risk factors of unscarred uterus includes grandmultiparity, cephalopelvic disproportion, fetal macrosomia, congenital uterine anamolies, mismanaged labor, labour augmentation with misoprostol, oxytocin and prostaglandin gel application of fundal pressure, placenta accreta. ${ }^{3}$ Rarely intrauterine manipulations such as internal podalic version and breech extraction are also known risk factors. The incidence after myomectomy is extremely low. ${ }^{4}$

Uterine rupture is an obstetrical complication which is severe and life threating and associated with significant maternal and fetal morbidity and mortality. It is characterized by a tear in the uterine wall involving its full thickness, including the serosa. ${ }^{5}$

Uterine rupture in the unscarred uterus is rare and its incidence is higher in developing than in developed countries. $^{6}$

\section{METHODS}

A retrospective analysis of unscarred uterine rupture cases was conducted at the Department of Obstetrics and Gynaecology Jhalawar Medical college Jhalawar Rajasthan between January 2009 to December 2016. 
After collecting relevant data from the operation theatre record, each patient case record was scrutinized regarding incidence, age, parity, antenatal high-risk factor, management complications and fetal outcome. Institutional ethical committee approval was obtained for the study.

Information about the total number of deliveries and of caesarean during the study period was obtained from the Medical record department.

\section{Inclusion criteria}

All the cases of uterine rupture without any previous scar or any other previous uterine operation after 36 weeks of gestation were included.

\section{Exclusion criteria}

Uterine rupture due to previous cesarean scar and any other operation on uterine was excluded.

\section{RESULTS}

During this study period of 8 years 61961 deliveries were recorded and this study period total uterine rupture were 30 in which $19(.03 \%)$ cases had scarred rupture uterus and $11(.01 \%)$ cases had unscarred rupture uterus.

Table 1: Incidence of unscarred uterine rupture.

\begin{tabular}{|lll|}
\hline & Number & Percentage \\
\hline Total rupture & 30 & 0.04 \\
\hline Scarred uterus & 19 & 0.03 \\
\hline Unscarred uterus & 11 & 0.01 \\
\hline
\end{tabular}

The incidence of unscarred uterine rupture is $0.01 \%$ or $1 / 10,000$ deliveries and incidence of scarred uterine rupture is $0.03 \%$.

In the present study most, common cause of unscarred uterine rupture is Multiparty 4 (36.36\%).

Table 2: In showing distribution according to Age $\mathbf{n = 1 1}$.

\begin{tabular}{|lll|}
\hline Age & Number & Percentage \\
\hline$<20$ & 1 & 9.09 \\
\hline $21-25$ & 2 & 18.18 \\
\hline $26-30$ & 5 & 45.45 \\
\hline $31-35$ & 3 & 27.27 \\
\hline
\end{tabular}

The maximum number of patient $(45.45 \%)$ are in age group of 26 to 30 years. Only one patient $(9.09 \%)$ is of less than 20 years.

In our study most, common complication was haemorrhage shock 7 (63.63\%). Maternal mortality was 1 $(9.09 \%)$ and perinatal mortality was high $8(72.72 \%)$.
Table 3: Distribution according to parity $n=11$.

\begin{tabular}{|lll|}
\hline Parity & Number & Percentage \\
\hline 1 & 1 & 9.09 \\
\hline 2 & 2 & 18.18 \\
\hline 3 & 3 & 27.27 \\
\hline 4 or $>4$ & 5 & 45.45 \\
\hline
\end{tabular}

The maximum number $5(45.45 \%)$ of patient are para 4 or $>4$ only $1(9.09 \%)$ is primipara.

Table 4: Causes of unscarred rupture uterus $(n=11)$

\begin{tabular}{|lll|}
\hline Cause & Number & Percentage \\
\hline Multiparity & 4 & 36.36 \\
\hline Obstructed labour & 3 & 27.27 \\
\hline Use of oxytocin & 1 & 9.09 \\
\hline Prostaglandine gel induction & 1 & 9.09 \\
\hline Mismanaged labour & 1 & 9.09 \\
\hline Mesoprostol drug & 1 & 9.09 \\
\hline
\end{tabular}

Second most common cause is obstructed labour, other causes are use of oxytocin, prostaglandin, mesoprostol and mismanaged labour. Most of the patient were presented with haemorrhagic shock 8 (72.72\%) and absent fetal heart 7 (63.63\%). Maximum patients had multiple symptoms.

Table 5: Clinical symptoms of unscarred rupture uterus

\begin{tabular}{|lll|}
\hline Clinical feature & Number & Percentage \\
\hline Hemorrhagic shock & 8 & 72.72 \\
\hline Abdominal pain & 6 & 54.54 \\
\hline Vaginal bleeding & 5 & 45.45 \\
\hline Loss of uterine contractility & 6 & 54.54 \\
\hline Absent foetal heart rate & 7 & 63.63 \\
\hline
\end{tabular}

Most of the patient were presented with hemorrhagic shock 8 (72.72\%) and absent fetal heart 7 (63.63\%). Maximum patients had multiple symptoms. Majority of cases $8(72.72 \%)$ were in 2 nd stage of labour during rupture.

Subtotal hysterectomy was done in $8(72.72 \%)$ patient, Total hysterectomy done in $2(18.18 \%)$ and repair of rupture uterus with tubal ligation was done in only 1 $(9.09 \%)$ patient.

\section{DISCUSSION}

In our study incidence of unscarred uterine rupture was $.01 \%$ or $1 / 10,000$ deliveries. This study was similar with the study done by Ahmadi et al. who had a figure of $.03 \%$ or $3 / 10,000$ deliveries. $^{7}$

In our study majority of patients $9(81.8 \%)$ were unbooked this is similar with the study done by Rasmi et al figured as $80 \% .^{8}$ 
The maximum patients were in age group of 26-30 years $5(45.45 \%)$

In our study maximum patient $5(45.45 \%)$ were of para 4 or $>4$. This is more as compared to study done by Golen et al (31\%) uterine rupture occurred in women with parity of more than $5 .^{9}$ Schrinky et al found that 7 out of 22 women $(32 \%)$ who had unscarred uterine rupture had a parity of greater than $4 .^{10}$

In our study most common cause of unscarred uterine rupture were multiparity $4(36.36 \%)$ this is similar with the study done by Thisted DL et al and Suner SL et al. ${ }^{1,11}$ A pathophysiological explanation of this may be the degree of myometrial fragidity which is acquired with successive pregnancies. Second most common cause of unscarred rupture uterus was obstructed labour 3 $(27.27 \%)$. The risk factors commonly associated with unscarred rupture uterus include multiparity, obstructed labour, use of uterotonic drugs for labour induction and augmentation, uterine anamolies and intrauterine manipulation. ${ }^{5}$

Use of oxytocin during labour is a risk factor for uterine rupture which is found in many instances in the literature. ${ }^{12}$ In present study oxytocin was routinely used, but in low dose. Nevertheless, even in the event of controlled administration in our study it is responsible for $1(9.09 \%)$ case.

Heckel et al reported that induction with prostaglandin confer the highest risk of uterine rupture. ${ }^{12}$ Furthermore, proper use of partogram for monitoring patient in labour could help in early diagnosis of poor progress of labour as well as timely surgical intervention. In this study 1 $(9.09 \%)$ rupture was due to prostaglandine gel.

When using misoprostol, it is important not to exceed the dose of 25 microgram intravaginally and to observe an interval of 4 to 6 hours between administered dose. Currently in France, the National Agency for the safety of Medicines and Medical products (ANSM) has warned against using Misoprostol to induce labour with a viable fetus. ${ }^{13}$ It is responsible for $1(9.09 \%)$ case in our study.

The most common presenting symptoms in our study was haemorrhagic shock, pain abdomen, vaginal bleeding and fetal distress.

If a gravid woman presents with hypotension, abdominal pain, fetal distress and vaginal bleeding, rupture uterus should be considered. ${ }^{14}$

Most of the rupture occurred in 2nd stage of labour 9 $(81.81 \%)$ and only $2(18.18 \%)$ rupture occurred before labour. This study is similar with the study done by Nahum G (86\% and $14 \%$ respectively). ${ }^{15}$
In our study maternal mortality was 1 (9.09\%). This study was comparable with the study by Ahmadi et al in which it was $7.1 \% .^{7}$

In our study perinatal mortality was $6(54.54 \%)$ that is less as compare to the study done by Schrinsky and Benson that is $64.6 \% .^{10}$

\section{CONCLUSION}

Uterine rupture in the unscarred uterus remains an exceptional serious uterine complication which causes high maternal and fetal morbidity and mortality. The main risk factors found in the literature and our study are multiparity, obstructed labour, use of oxytocin and prostaglandin.

\section{REFERENCES}

1. Suner S, Jagminas L, Peipert JF, Linakis J. Fatal spontaneous rupture of a gravid uterus: Case report and literature review of uterine rupture. J Emerg Med. 1996;14:181-5.

2. Ankelesaria BS, Savaliya MV. Rupture Uterus. In: Krishna U, Tank DK, Daftary S (eds). Pregnancy at Risk, Current concepts. $4^{\text {th }}$ ed. New Delhi, Jaypee Brothers (p)Ltd; 2001:468-71.

3. Sakr R, Berkane N, Barranger E, Dubernard G, Darai E, Uzan S. Unscarred uterine rupture--case report and literature review. Clin Exp Obstet Gynecol. 2007;34(3):190-2.

4. Golan D, Aharoni A, Gonen R, Boss Y, Sharf M. Early spontaneous rupture of the post myomectomy gravid uterus. Int J Gynaecol Obstet. 1990;31:16770.

5. Mavromatidis G, Karavas G, Margioula-Siarkou C, Petousis S. Spontaneous postpartum rupture of an intact uterus: a case report. J Med Clin Res. 2015;1:56-8.

6. Zwart JJ, Richters JM, Öry F, De Vries JI, Bloemenkamp KW, Van Roosmalen J. Uterine rupture in the Netherlands: a nationwide populationbased cohort study. BJOG: Int J Obstet Gynaecol. 2009;116:1069-80.

7. Ahmadi S, Nouira M, Bibi M, Boughuizane S, Saidi $\mathrm{H}$, Chaib A, Khairi $\mathrm{H}$. Uterine rupture of the unscarred uterus. About 28 cases. Gynecologie Obstetrique Fertilite. 2003;31:713-7.

8. Radhakrisknan G, Vaid NB, Agarwal N. Rupture uterus--changing Indian scenario. J Indian Med Assoc. 2001;99:634-7.

9. Golan A, Sandbank O, Rubin A. Rupture of pregnant uterus. Obstet Gynnecol Surv.Aprv.1980 56: 549-54.

10. Schrinsky DC, Benson RC. Rupture of the pregnant uterus: a review. Obstet Gynecol Surv. 1978;33:21732.

11. Thisted DL, Mortensen LH, Krebs L. Uterine rupture without previous caesarean delivery: a populationbased cohort study. Eur J Obstet Gynecol Reprod Biol. 2015;195:151-5. 
12. Heckel S, Ohl J, Dellenbach P. Rupture of an unscarred uterus at full term after an intracervical application of dinoprostone (Prepidil) gel. Rev Fr Gynecol Obstet. 1993;88:162-4.

13. ANSM. Warning about the potential risk of f-lable use of Cytotec (mesoprostol) in triggering childbirth and other gynecological use. 2013:130225.

14. Mazzone MF, Woolever J. Uterine rupture in a patient with an unscarred uterus: a case study. WMJMADISON. 2006;105:64.
15. Nahum G. Uterine rupture in pregnancy. Medline. 2010;10. Available https://reference.medscape.com/article/275854overview

Cite this article as: Verma M, Bairwa R. Unscarred uterine rupture: a retrospective analysis in tertiary center. Int J Reprod Contracept Obstet Gynecol 2018;7:1318-21. 